\title{
DESAIN BIS AIR RAMAH LINGKUNGAN SEBAGAI SARANA TRANSPORTASI ALTERNATIF DI PROVINSI DKI JAKARTA
}

\author{
Bambang Sudjasta ${ }^{1}$, Purwo Joko Suranto ${ }^{2}$ \\ Program Studi Teknik Perkapalan, Universitas Pembangunan Nasional “Veteran” Jakarta, Jakarta Selatan 12 \\ email $^{1}$ : bambangsudjasta58@gmail.com
}

\begin{abstract}
Flood Canal was built to reduce the impact of flood during the rainy season that is river catching / times that passes in The Special Areas of The Capital of Jakarta and can accommodate the flood from Depok and Bogor. The city government is also building a mass transportation mode in Jakarta that integrates railway lines, light rail transit, roads, busway and subway networks targeted for completion in 2017 and will be integrated with the outer ring train, but if the floods are partially paralyzed. For this reason, it is necessary to empower the Flood Canal function as an alternative transportation infrastructure that is environmentally friendly water bus with a capacity of 30 passengers that can operate even in flood condition. A number of preliminary studies of water buses of earlier models and concepts have been conducted to obtain a suitable and feasible prototype to operate in the flow of West and East Canal Floods. To obtain a good water bus size calculation based on comparison ratio, general arrangement design, hull form design with $C A D$, hydrostatic calculation, engine power estimate and determination of required energy, stability calculation. The goal is as an environmentally friendly alternative transportation mode, with the advantage of being able to operate even in flood situations. It is expected to change the customs of the community for the canal to be the front of the house instead of the back of the house.
\end{abstract}

Keywords: flood canal, water bus, alternative mode of transportation, environmentally friendly

\section{PENDAHULUAN}

Komitmen Pemprov DKI Jakarta mengembangkan sarana dan prasarana transportasi bertujuan mengurangi kemacetan lalu lintas, diharapkan waktu tempuh transportasi dapat dipersingkat. Sarana dan prasarana yang terus dikembangkan berbasis darat antara lain Busway, Commuter Line / KRL, Light Rail Transit (LRT) yaitu kereta api ringan, Mass Rapid Transit (MRT). Sebagai alternatif maka perlu dipikirkan sarana dan prasarana berbasir air.

Perlu diberdayakan fungsi kanal banjir yang ada di Provinsi DKI Jakarta dengan merencanakan Bis Air yang dapat dioperasikan baik pada Kanal Banjir Barat dan Timur. Desain sarana transportasi ini adalah berupa bis air yang dapat mengangkut 30 penumpang terbuat dari bahan aluminium, mesin inboard, memanfaatkan energi surya, kecepatan 7 knots. Persyaratan transportasi ini media air kanal harus terbebas dari sampah dan debit air pada kanal ini relatif stabil agar putaran baling-baling dapat berfungsi efektif.

Pemanfaatan bis air ini dapat membantu mengurangi kemacetan transportasi jalan raya.
Untuk memenuhi kriteria ramah lingkungan maka alat kebutuhan listrik bis air dirancang menggunakan energi surya.

\section{Perumusan Masalah}

Kanal Banjir Barat dibangun sejak masa penjajahan Belanda, diharapkan mampu mengurangi bencana banjir sehingga pada saat musim penghujan aktivitas masyarakat tidak terganggu. Untuk mengoptimalkan fungsi keberadaan Kanal Banjir Barat maupun Timur dapat dilakukan dengan membuat sarana transportasi air dengan bentuk Bis Air ramah lingkungan berkapasitas 30 penumpang, dengan keunggulan dapat beroperasi baik dalam keadaan normal maupun dalam keadaan banjir sebagai moda transportasi alternatif serta sebagai sarana rekreasi bagi masyarakat sekitar kanal.

\section{Tujuan Penelitian}

Tujuan penelitian ini adalah melakukan perancangan bis air ramah lingkungan berkapasitas 30 penumpang sebagai sarana transportasi alternatif di kanal banjir Provinsi DKI Jakarta, yaitu:

a. Menentukan ukuran pokok;

b. Membuat rencana garis bentuk bis air dengan program Maxsurf; 
c. Membuat rencana umum;

d. Menentukan konstruksi;

e. Penentuan daya penggerak bis air;

f. Perhitungan penggunaan energi surya;

g. Analisis stabilitas.

\section{TINJAUAN PUSTAKA}

Kanal Banjir Jakarta

Kanal Banjir Barat (KBB), berawal dari daerah Manggarai ke arah barat melewati Pasar Rumput, Dukuh Atas, lalu membelok ke arah barat laut di daerah Karet Kubur. Selanjutnya ke arah Tanah Abang, Tomang, Grogol, Pademangan, dan berakhir di Muara Angke, lihat gambar berikut.
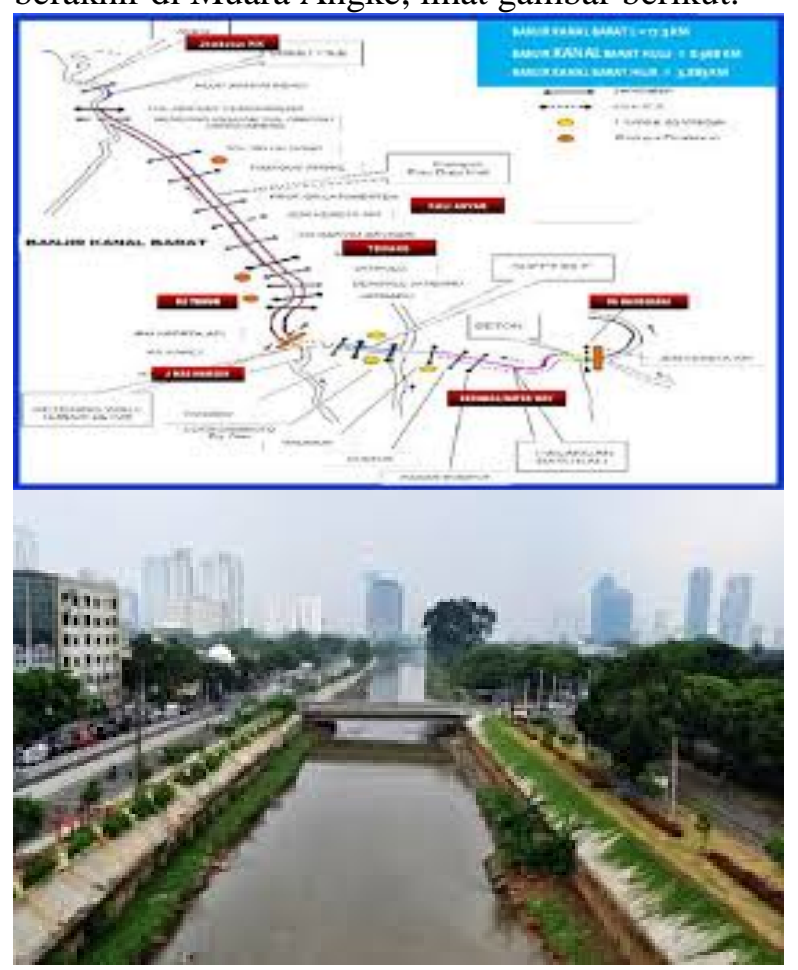

Gambar 1. Kanal Banjir Barat

Kanal Banjir Timur (KBT) telah selesai sejak akhir tahun 2010. Proyek Kanal Banjir Timur dapat menampung beberapa kali atau sungai di sekitar KBT seperti menampung aliran Kali Cipinang, Kali Sunter, Kali Buaran, Kali Jati Kramat dan Kali Cakung. Kanal dengan panjang 23,5 km dan lebar \pm 100 meter ini melintasi 13 kelurahan yaitu dua kelurahan di Jakarta Utara dan 11 kelurahan di Jakarta Timur, lihat tabel dan gambar berikut.
Tabel 1. Kelurahan yang dilalui KBT

\begin{tabular}{|c|l|r|}
\hline No & \multicolumn{1}{|c|}{ Kelurahan } & Meter \\
\hline 1 & Cipinang Besar Selatan & 770 \\
\hline 2 & Cipinang Muara & 758 \\
\hline 3 & Pondok bamboo & 2.072 \\
\hline 4 & Duren Sawit & 1.705 \\
\hline 5 & Pondok Kelapa & 1.93 \\
\hline 6 & Malaka Jaya & 4.33 \\
\hline 7 & Malaka Sari & 7.17 \\
\hline 8 & Pondok kopi & 1.876 \\
\hline 9 & Pulo Gebang & 3.137 \\
\hline 10 & Ujung Menteng & 2.834 \\
\hline 11 & Cakung Timur & 2.019 \\
\hline 12 & Rorotan & 3.065 \\
\hline 13 & Marunda & 3.615 \\
\hline & \multicolumn{2}{|c|}{ Total } \\
\hline
\end{tabular}

Sumber: Bappeda Provinsi DKI Jakarta
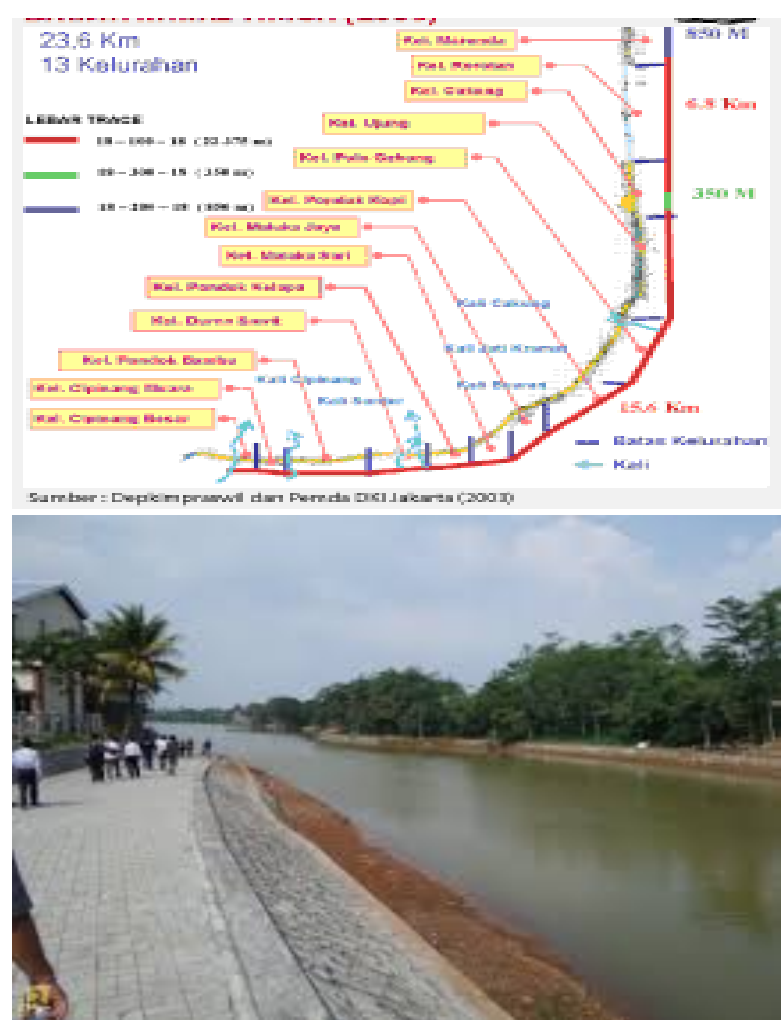

Gambar 2. Kanal Banjir Timur

\section{Moda Transportasi di Jakarta}

Moda transportasi massal di Jakarta yang direncanakan akan mengintegrasikan jalur kereta, jaringan jalan, busway, maupun subway ditargetkan rampung tahun 2018. Transportasi berbasis rel telah dikembangkan dengan jenis Light Rail Transit (LRT) dan Mass Rail Transportation (MRT) yang akan diintegrasikan. MRT yang sedang dibangun adalah jalur Lebak Bulus-Dukuh Atas sepanjang 14 km, LRT jalur Cibubur-Duku Atas. Seperti dikutip dari Media Online Pemprov DKI Jakarta, masalah transportasi merupakan salah satu dari 10 isu strategis yang ditetapkan.. Selain tranportasi, masalah lain segera dikerjakan adalah pengendalian 
banjir, perampingan birokrasi, pendidikan, lingkungan hidup, dan kesehatan.

\section{Konsep Desain Bis Air}

Berdasarkan data-data desain terdahulu serta berdasarkan keadaan fisik dari Kanal Banjir dimungkinkan memberdayakan sarana moda transportasi altenatif yaitu bis air kapasitas 30 penumpang. Panjang bis air 15 meter, lebar 3,5 meter, tinggi 1,5 meter, sarat 0,90 meter dengan kecepatan sekitar 5 sampai dengan 7 knots. Dengan catatan bahwa ukuran bis air tersebut masih perkiraan, akan dilakukan perubahan berdasarkan kondisi fisik kanal terutama saat pasang surut dan ukuran tiang-tiang jembatan yang melintasi kanal. Ukuran pokok demikian disesuaikan dengan kondisi daerah operasionalnya, memungkinkan bis air dapat dengan mudah untuk olah gerak.

\section{Daerah Operasi}

Daerah operasi bis air untuk KBB dari Kelurahan Manggarai sampai ke Kelurahan Karet Jakarta Selatan atau dari Kelurahan Karet menuju Muara Angke Jakarta Utara. Daerah operasi bis air untuk Kanal Banjir Timur dari Kelurahan Cipinang sampai ke Kelurahan Pulo Gebang atau dari Kelurahan Pulo Gebang menuju Kelurahan Marunda Jakarta Utara.

\section{Aspek Teknik Desain Bis Air di Kanal}

Kesesuaian kondisi perairan pelayaran di daerah kanal secara umum tergantung 4 (empat) faktor, sebagai berikut:

a. Dimensi dan kelurusan (alingment) kanal.

b. Kondisi aliran air (flow condition).

c. Kondisi gelombang dan angin.

d. Bagian-bagian menonjol pada dasar kanal.

Penentuan ukuran pokok didasarkan pada:

a. Ukuran melintang kanal.

b. Tata ruang sekitar aliran kanal.

c. Tinggi dan ukuran jembatan yang melintasi kanal.

Rekomendasi standar penentuan ukuran pokok kapal (bis air) maksimum oleh jurnal ESCAP (Economic and Social Commission for Asia and Pasific) yaitu hasil studi yang dilakukan oleh Delf, bidang Hydrodinamycc, dari Netherlands tentang ratio kapal-kapal yang beroperasi di kanal, seperti tabel di bawah ini:

Tabel 2. Standar ESCAP

\begin{tabular}{|c|l|c|c|}
\hline $\begin{array}{c}\text { Krite } \\
\text { Ria }\end{array}$ & \multicolumn{1}{|c|}{ Penentuan } & \multicolumn{2}{|c|}{ Pelayaran } \\
\cline { 3 - 4 } h/Ts & $\begin{array}{l}\text { Kemampuan Steering; } \\
\text { Clearance lurus kapal }\end{array}$ & 1,4 & 2 Arah \\
\hline bt/Bs & $\begin{array}{l}\text { Lebar kanal terhadap } \\
\text { lebar kapal }\end{array}$ & 4,0 & 2,0 \\
\hline Vmaks & $\begin{array}{l}\text { Kecepatan kapal } \\
\text { maksimum }\end{array}$ & $\begin{array}{c}2,4-2,8 \\
\text { m/det }\end{array}$ & $\begin{array}{c}1,4-1,7 \\
\text { m/det }\end{array}$ \\
\hline Rmaks & Radius putaran kanal & $6 \mathrm{Ls}$ & $4 \mathrm{Ls}$ \\
\hline
\end{tabular}

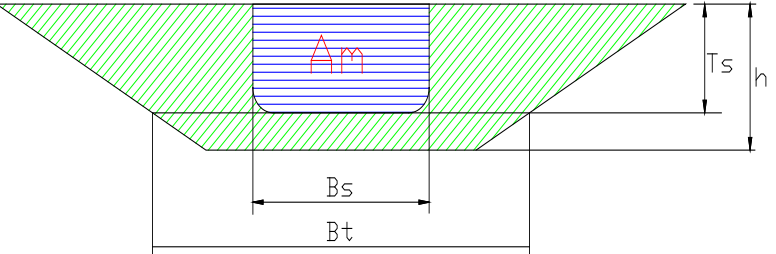

Gambar 3. Sketsa Penampang Kanal

Keterangan:

$\mathrm{h}=$ Kedalaman kanal

Ts = Tinggi sarat kapal

$\mathrm{b}_{\mathrm{T}}=$ Lebar kanal pada posisi lunas

Bs = Lebar kapal (bis air)

Ls = Panjang kapal (bis air)

$\mathrm{Am}=$ Penampang tengah kapal (bis air)

\section{Ketentuan:}

1. Tinggi sarat bis air tergantung dari air surut minimum.

2. Lebar bis air tergantung dari bagian-bagian yang menonjol pada lebar kanal.

3. Tinggi rumah geladak tergantung dari tinggi jembatan yang terendah yang melintasi kanal.

\section{Desain Bis Air}

\section{Ukuran Utama}

Ukuran utama (main dimension) sebuah kapal (bis air) meliputi panjang (L), lebar (B), tinggi (H), sarat (T), koefisien bentuk, berat kapal kosong (Lwt) dan daya angkut (Dwt). Koefisien bentuk sebuah kapal terdiri dari koefisien blok (Cb), koefisien tengah kapal $(\mathrm{Cm})$, koefisien garis air $(\mathrm{Cw})$, dan koefisien prismatik (Cp).

Syarat yang perlu diperhatikan menentukan ukuran utama adalah:

a. Displacement $(\Delta)$ adalah berat bis air keseluruhan atau berat air yang dipindahkan oleh badan kapal yang tercelup.

b. Tonnage adalah ukuran volume ruang bis air.

c. Kecepatan dinas (Vs) adalah kecepatan normal yang diinginkan pada saat bis air berlayar.

Metode menentukan ukuran utama kapal umumnya digunakan metode perbandingan (comparison method) dan metode iterasi (trial and error). Metode perbandingan digunakan karena relatif lebih mudah, dan metode iterasi diperlukan untuk ketelitian. Koreksi terhadap ukuran utama dilakukan dengan membandingkan $\mathrm{L} / \mathrm{B}, \mathrm{L} / \mathrm{H}, \mathrm{B} / \mathrm{T}$ dan $H / T$. Sedangkan untuk ratio perbandingan ukuran pokok kapal (bis air), ditunjukkan pada tabel 3, di bawah ini: 
Tabel 3. Perbandingan Ukuran Pokok Bis Air

\begin{tabular}{|c|c|}
\hline $\begin{array}{c}\text { Perbandingan } \\
\text { Ukuran Pokok Kapal } \\
\text { (Bis Air) }\end{array}$ & Ratio \\
\hline L/B & $3,50 \mathrm{~s} / \mathrm{d} 5,00$ \\
B/T & $2,25 \mathrm{~s} / \mathrm{d} \mathrm{6,00}$ \\
D/T & $1,20 \mathrm{~s} / \mathrm{d} 2,70$ \\
\hline
\end{tabular}

Tabel 4. Koefisien Bentuk

\begin{tabular}{|l|l|}
\hline $\mathrm{Cb}=\frac{\Delta}{\mathrm{Lpp} \times \mathrm{B} \times \mathrm{d} \times 1,025}$ & $\mathrm{Cm}=0,9+0,1 \times \mathrm{Cb}^{0,5}$ \\
\hline $\mathrm{CW}=\frac{1+(2 \times \mathrm{Cb})}{3}$ & $\mathrm{Cp}=\cdot \frac{\mathrm{Cb}}{\mathrm{Cm}}$ \\
\hline
\end{tabular}

\section{Rencana Garis, Hidrostatika, dan Bonjean}

Perancangan rencana garis didahului pembuatan curve of section area (CSA). CSA tersebut menggambarkan besarnya luasan tiap-tiap section bis air.

Kurva hidrostatika menunjukkan karakteristik kemampuan apung serta parameter bis air dalam berbagai kondisi. Kurva-kurva yang digambarkan antara lain: displacement, luasan garis air, titik tekan ke atas, koefisien-koefisien, dan metacenter.

Kurva bonjean dibuat berdasarkan luasan tiaptiap ordinat, dibuat sampai dengan geladak. Kegunaan kurva bonjean antara lain untuk: perhitungan peluncuran kapal dan perhitungan rencana kapasitas.

\section{Rencana Umum}

Rencana umum adalah rencana pembagian kompartemen, penempatan peralatan dan perlengkapan kapal/bis air antara lain:

- Sekat-sekat kedap air;

- Peralatan dan perlengkapan deck;

- Peralatan akomodasi;

- Permesian dan peralatan nautis;

- Perlengkapan keselamatan pelayaran;

- Peralatan pemadam kebakaran.

\section{Konstruksi dan Daya Penggerak}

\section{Konstruksi Bis Air}

Konstruksi bis air ini direncanakan berbahan baku aluminium. Pilihan pada aluminium dengan pertimbangan berbobot ringan namun memenuhi kriteria kekuatan. Material aluminium tersebut dibentuk menjadi pelat, frame, web, dan stiffener. Penentuan tebal lapisan pelat dan modulus-modulus elemen konstruksi mengacu pada peraturan klasifikasi dan konstruksi kapal yang dikeluarkan oleh Biro Klasifikasi dan/atau peraturan Non Convention Vessel Standard (NCVS). Bagianbagian bis air yang dihitung tebal lapisan pelat dan modulus-modulus adalah: pelat kulit, geladak, konstruksi alas, gading-gading, sekat, linggi haluan dan buritan serta lain-lain.

\section{Daya Penggerak}

Daya penggerak efektif kapal (Pe)

$\mathrm{Pe}=\mathrm{R} \times \mathrm{Vs}$

$\mathrm{R}$ adalah hambatan kapal yang terdiri dari: hambatan gesek, gelombang, bentuk, udara, dan hambatan lain-lain.

$\mathrm{R}=\operatorname{Cr} \times\left(1 / 2 \times \rho \times \mathrm{V}^{2} \times \mathrm{S}\right)$

Vs $=$ kecepatan kapal

\section{Pemanfaatan Energi Surya}

Manfaat pengembangan penggunaan panel surya untuk bidang transportasi antara lain ditujukan untuk menghemat energi dan sekaligus ramah lingkungan. Energi surya dalam desain bis air ini dimanfaatkan untuk peralatan-peralatan yang menggunakan energi listrik.

\section{Tonnage dan Stabilitas}

\section{Tonnage}

Tonnage merupakan volume ruang pada sebuah kapal dengan satuan Register Tonnage (RT), dimana $1 \mathrm{RT}=100 \mathrm{ft}^{3}$ atau setara dengan 2,83 $\mathrm{m}^{3}$. Dua macam pengukuran tonnage yaitu Gross Tonnage (GT) dan Net Tonnage (NT).

$\mathrm{GT}=\mathrm{K}_{1} \times \mathrm{V}$

$\mathrm{V}=$ Volume total dari semua ruang tertutup

$\mathrm{K}_{1}=0,2+0,02 \log \mathrm{V}$

$\mathrm{NT}=\mathrm{K}_{2} \times \mathrm{Vc} \times\left(. \frac{4 \times \mathrm{T}}{5 \times \mathrm{H}}\right)^{2}$

$\mathrm{V}_{\mathrm{c}}=$ Volume total ruang muat

$\mathrm{K}_{2}=0,2+0,002 \log \mathrm{Vc}$

\section{Stabilitas}

Stabilitas kapal sangat dipengaruhi oleh kedudukan 3 (tiga) buah titik, yaitu:

a. Titik pusat berat bis air / center of gravity (G);

b. Titik pusat gaya tekan ke atas / center of buoyancy (B) dari air yang dipindahkan oleh badan bis air;

c. Titik metacenter (M).

Stabilitas yang baik apabila letak titik G berada di bawah titik $\mathrm{M}$ dan berada di atas titik $\mathrm{B}$. 


\section{METODOLOGI PENELITIAN Alur Metode Penelitian}

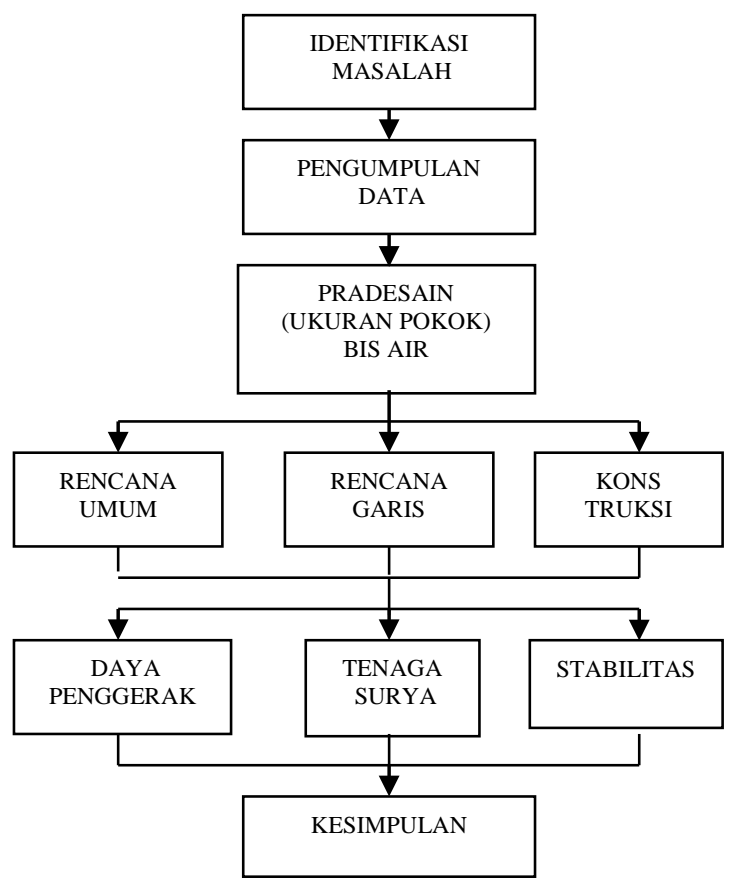

Gambar 4. Bagan Alir Metode Penelitian

\section{Uraian Metode Penelitian}

Tabel 5. Uraian Metode Penelitian

\begin{tabular}{|c|c|c|}
\hline Kegiatan & Metode & Luaran \\
\hline $\begin{array}{l}\text { Identifikasi } \\
\text { masalah dan } \\
\text { Pengumpulan } \\
\text { Data }\end{array}$ & $\begin{array}{l}\text { Literatur, } \\
\text { survey }\end{array}$ & $\begin{array}{l}\text { Data-data bis air } \\
\text { sejenis sebagai } \\
\text { pembanding dan } \\
\text { data-data kanal }\end{array}$ \\
\hline Prarancangan & $\begin{array}{l}\text { Rasio ukuran } \\
\text { pokok yang } \\
\text { sudah ada: } \\
\text { L/B, B/T, D/T }\end{array}$ & $\begin{array}{l}\text { Ukuran Pokok } \\
\text { Bis Air yaitu: } \\
\text { panjang, lebar, } \\
\text { tinggi, dan sarat }\end{array}$ \\
\hline $\begin{array}{l}\text { Perkiraan Berat } \\
\text { Bis Air }\end{array}$ & $\begin{array}{l}\text { Acuan kapal } \\
\text { pembanding } \\
\text { dan rumus } \\
\text { umum }\end{array}$ & $\begin{array}{l}\text { Dwt: berat } \\
\text { penumpang, } \\
\text { bbm, pelumas, } \\
\text { air pendingin, } \\
\text { ABK. } \\
\text { Lwt: berat } \\
\text { konstruk, mesin, } \\
\text { perlengkapan. }\end{array}$ \\
\hline $\begin{array}{l}\text { Penentuan } \\
\text { Rencana Umum } \\
\text { (General } \\
\text { Arrangement) }\end{array}$ & $\begin{array}{l}\text { Regulasi } \\
\text { umum kapal } \\
\text { aluminium, } \\
\text { dan software } \\
\text { CAD }\end{array}$ & $\begin{array}{l}\text { Tata letak dan } \\
\text { akses ruangan, } \\
\text { lokasi } \\
\text { perlengkapan. } \\
\text { Tampak } \\
\text { samping, depan, } \\
\text { dan atas. }\end{array}$ \\
\hline $\begin{array}{l}\text { Penetuan } \\
\text { Peralatan Bis } \\
\text { Air }\end{array}$ & $\begin{array}{l}\text { Regulasi kapal } \\
\text { aluminium, } \\
\text { dan pemilihan } \\
\text { peralatan }\end{array}$ & $\begin{array}{l}\text { Sistem } \\
\text { penggerak, } \\
\text { peralatan } \\
\text { akomodasi, } \\
\text { tambat, } \\
\text { keselamatan. }\end{array}$ \\
\hline $\begin{array}{l}\text { Penggambaran } \\
\text { Rencana Garis }\end{array}$ & $\begin{array}{l}\text { Menggunakan } \\
\text { Software }\end{array}$ & $\begin{array}{l}\text { Body plan, sheer } \\
\text { plan, halfbreadth }\end{array}$ \\
\hline
\end{tabular}

\begin{tabular}{|l|l|l|}
\hline (Lines Plan) & Marxshurf & plan \\
\hline $\begin{array}{l}\text { Perhitungan } \\
\text { Hidrostatika }\end{array}$ & Menggunakan & $\begin{array}{l}\text { Displasemen, } \\
\text { Rumus Umum } \\
\text { KB, LCB, TMB, } \\
\text { LMB, AWL, } \\
\text { WSA, Cw, Cb, } \\
\text { Cm, Cp. }\end{array}$ \\
\hline $\begin{array}{l}\text { Penentuan } \\
\text { Konstruksi }\end{array}$ & $\begin{array}{l}\text { Peraturan Biro } \\
\text { Klasifikasi } \\
\text { kapal berbahan } \\
\text { aluminium }\end{array}$ & $\begin{array}{l}\text { Penentuan beban, } \\
\text { jumlah sekat, } \\
\text { frame, pelat } \\
\text { lambung, deck. }\end{array}$ \\
\hline $\begin{array}{l}\text { Penentuan Daya } \\
\text { Penggerak }\end{array}$ & $\begin{array}{l}\text { Dari kapal } \\
\text { pembanding }\end{array}$ & Bersaran BHP \\
\hline $\begin{array}{l}\text { Penghitungan } \\
\text { energi surya dan } \\
\text { instalasinya }\end{array}$ & $\begin{array}{l}\text { Perhitungan } \\
\text { umum }\end{array}$ & $\begin{array}{l}\text { Daya dihasilkan } \\
\text { dan rangkaian } \\
\text { instalasi }\end{array}$ \\
\hline $\begin{array}{l}\text { Perhitungan } \\
\text { Tonnage }\end{array}$ & Standar IMO & $\begin{array}{l}\text { Besaran volume } \\
\text { seluruh ruangan }\end{array}$ \\
\hline $\begin{array}{l}\text { Perhitungan } \\
\text { Stabilitas }\end{array}$ & $\begin{array}{l}\text { Menggunakan } \\
\text { Teori Stabilitas }\end{array}$ & $\begin{array}{l}\text { Standar stabilitas } \\
\text { dan periode oleng } \\
\text { muatan penuh }\end{array}$ \\
\hline
\end{tabular}

ANALISIS DAN PEMBAHASAN DATA Hasil Perhitungan Ukuran Pokok Bis Air

Ukuran utama bis air:

$\begin{array}{lll}\text { Loa } & =15,10 \mathrm{~m} ; & \mathrm{Cb}=0,55 \\ \text { Lwl }=14,62 \mathrm{~m} ; & \mathrm{Cw}=0,75 \\ \text { Breadth }=3,70 \mathrm{~m} ; & \mathrm{Cm}=0,70 \\ \text { Depth }=1,37 \mathrm{~m} ; & \mathrm{Cp}=0,786 \\ \text { Draft = } 0,86 \mathrm{~m} ; & \end{array}$

\section{Curve of Sectional Area (CSA)}

Pengukuran station curve of sectional area (CSA) bis air ini mengikuti CSA bis air pembanding.

Gambar curve of sectional area (CSA) menunjukkan persentase luasan setiap station dari station 0 (AP) sampai dengan station 20 (FP).

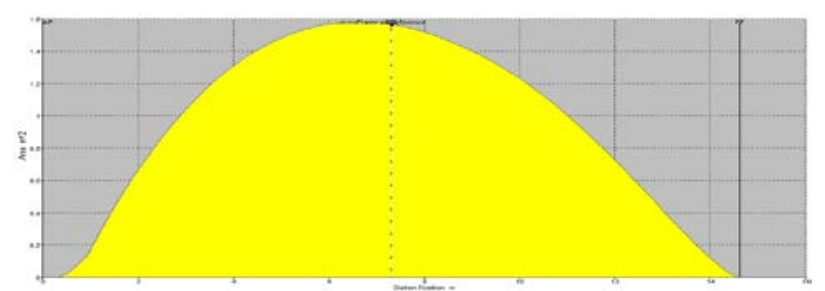

Gambar 5. Curve of Sectional Area (CSA)

\section{Rencana Garis}

Berdasarkan CSA tersebut selanjutnya dengan menggunakan software aplikasi Maxsurf dapat digambar rencana garis (lines plan) badan (hull) bis air. 


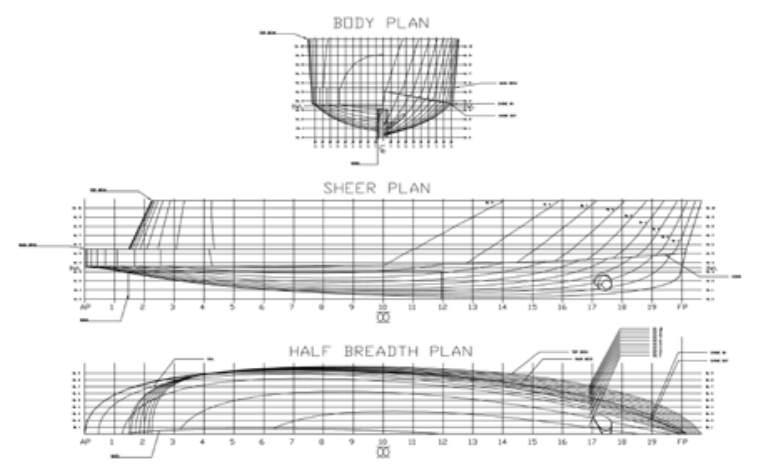

Gambar 6. Rencana Garis (Lines Plan) Bis Air

\section{Rencana Umum}

Kecepatan $=5$ sampai 7 knot

Mesin utama in board Yamaha = 2 x $60 \mathrm{hp}$;

Rencana umum konstruksi bangunan bis air terbuat dari bahan aluminium dengan kapasitas penumpang 30 orang dan crew 2 orang.

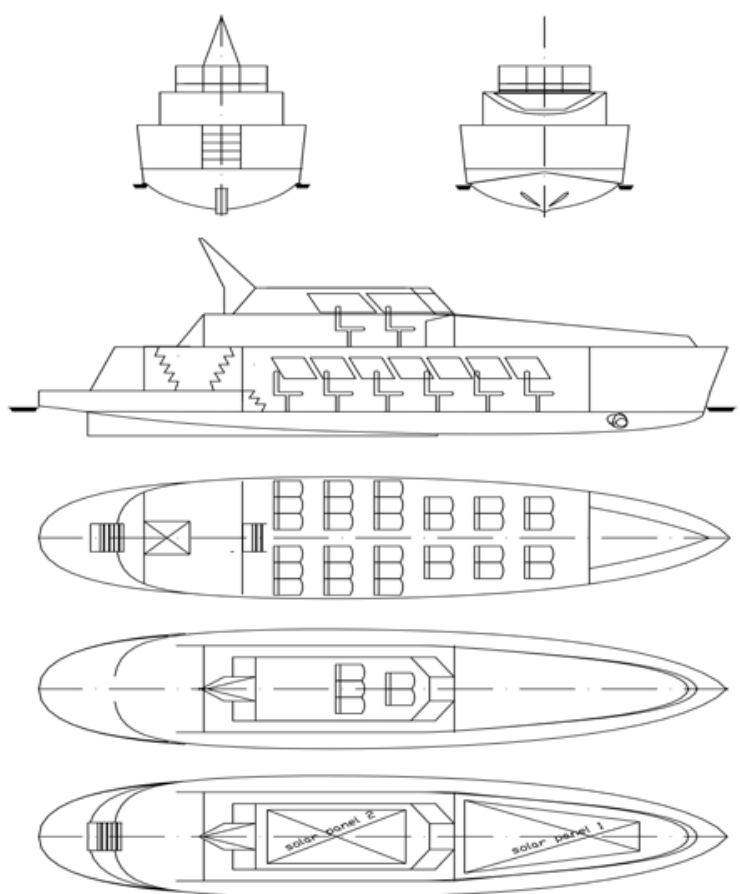

Gambar 7. Rencana Umum

\section{Konstruksi}

Pemilihan material aluminium:

1. Berat aluminium adalah setengah dari berat fiberglass untuk ukuran dan kekuatan struktur yang sama, sehingga lebih ringan dan lebih hemat bahan bakar atau hemat energi.

2. Aluminium tahan terhadap korosi sehingga menghemat pemeliharaan, dan memiliki batas umur teknis yang lebih panjang.

3. Aluminium dapat didaur ulang.

\section{Bahan dan konstruksi}

Aluminium grade-5000 dan grade-6000 kelas kelautan diakui di tingkat internasional dan dapat digunakan pada kapal. Aluminium Marine, Grade
5083 H116, tebal $6 \mathrm{~mm}$ dipasang pada bottom (dasar), samping (kulit), deck (geladak), dan cabin (ruang untuk penumpang).
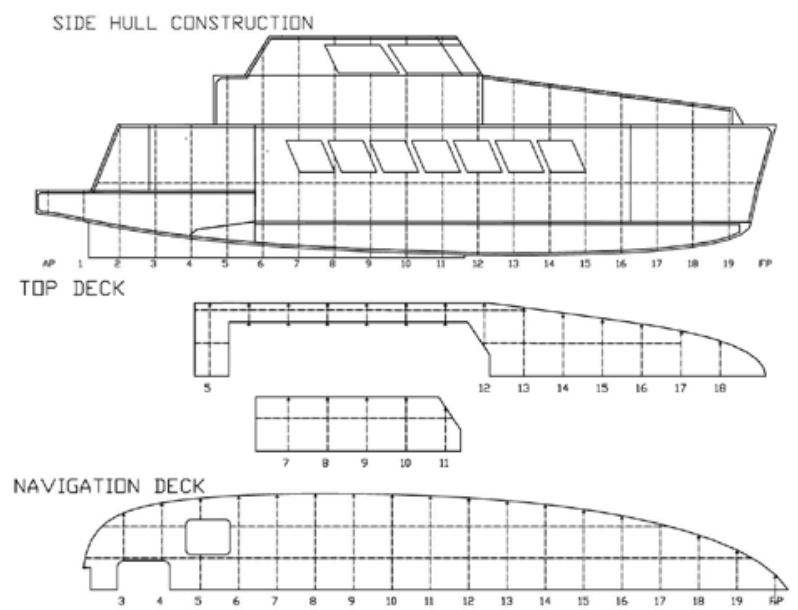

FRAME 10

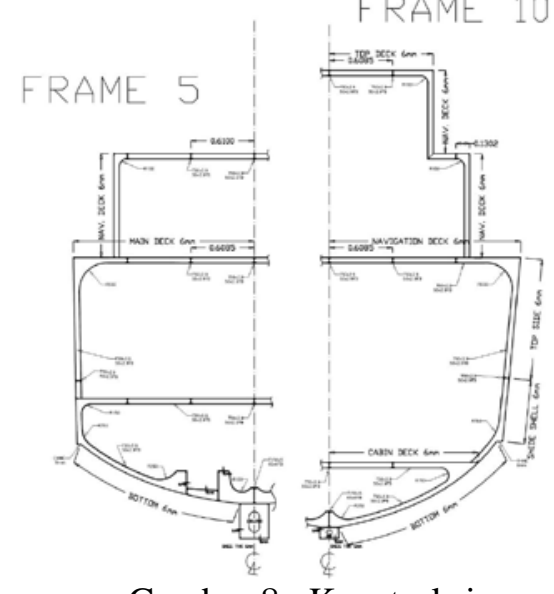

Gambar 8. Konstruksi

\section{Daya Mesin Penggerak}

Rumus Posdunine

Break horse power bis air desain (BHPd)

$$
=101,407 \mathrm{hp}=2 \times 60 \mathrm{hp}
$$

\section{Daya Listrik dari Panel Surya}

Instalasi pembangkit listrik dengan tenaga surya membutuhkan perencanaan mengenai kebutuhan daya:

- Jumlah pemakaian;

- Jumlah panel surya / solar cell;

- Jumlah baterai.

Tabel 6. Pemakaian Listrik

\begin{tabular}{|r|l|c|c|c|}
\hline No & Peralatan & Watt & Banyak & Jmlah \\
\hline 1 & Penerangan ruang & 20 & 10 & 200 \\
\hline 2 & Lampu sorot & 100 & 1 & 100 \\
\hline 3 & Telivisi & 75 & 1 & 75 \\
\hline 4 & Radio & 35 & 1 & 35 \\
\hline 5 & Komunikasi & 75 & 1 & 75 \\
\hline 6 & Air Condition & 600 & 2 & 1200 \\
\hline 7 & Lain-lain & 100 & 1 & 100 \\
\hline & \multicolumn{4}{|l}{} \\
\hline
\end{tabular}


Jumlah panel surya yang dibutuhkan, satu panel kita hitung 100 Watt (perhitungan adalah 5 jam maksimun tenaga surya):

- Kebutuhan panel surya: 1785 / $(100 \times 5)=4$ panel surya.

Jumlah kebutuhan baterai 12 Volt, masingmasing 100 Ah:

- Kebutuhan baterai minimun (baterai hanya digunakan 50\% untuk pemenuhan kebutuhan listrik), daya kita kalikan 2 x lipat: 1785 × $2=$ 3570 Watt hour $=3570 / 12$ Volt $/ 100$ Amp $=3$ baterai 100 Ah.

- Kebutuhan baterai (2 hari tanpa sinar matahari): $1785 \times 2 \times 2=7140$ watt hour $=7140 / 12$ Volt $/$ $100 \mathrm{Amp}=6$ baterai $100 \mathrm{Ah}$.

\section{Stabilitas}

a. Letak vertikal center of buoyancy (KB) $\mathrm{KB}=0,551 \mathrm{~m}$

b. Letak titik metacenter melintang dari buoyancy $\left(\mathrm{BM}_{\mathrm{T}}\right)=1,40 \mathrm{~m}$

c. Jarak titik metacenter melintang terhadap garis dasar $\left(\mathrm{KM}_{\mathrm{T}}\right)=1,951 \mathrm{~m}$

d. Titik berat

Berat bis air penumpang penuh $=25,59$ ton

Titik berat bis air KG

$\mathrm{KG}=1,02 \mathrm{~m}$

Harga $\mathrm{GM}_{\mathrm{T}}=0,931 \mathrm{~m}$

\section{Rolling period (periode oleng)}

Waktu / periode oleng adalah waktu dalam detik yang diperlukan untuk menyelesaikan satu gerakan oleng baik dari sisi kiri ataupun kanan.

Periode oleng $(\mathrm{t})=\frac{2 x i x V B}{V G M_{T}}$

Dimana $\mathrm{i}=$ radius gerasi $=(0,3 \mathrm{~B}$ sd. $0,45 \mathrm{~B}) \mathrm{m}$ $=1,665 \mathrm{~m}$

Sehingga periode oleng $(\mathrm{t})=6,64$ detik

Menurut Herner periode oleng yang baik jika t $\mathrm{x}$ $\sqrt{ }(\mathrm{g} / \mathrm{B})=$ terletak pada 8 sd. 14 detik.

Harga $t$ yang baik $=6,64 \times \sqrt{ }(9,81 / 3,7)$

$$
=10,812 \text { detik }
$$

Periode oleng $(\mathrm{t})$ dianggap baik sesuai terletak antara 8 sd. 14 detik.

\section{Tonnage}

Tonnage merupakan volume ruang pada kapal dengan satuan Register Tonnage (RT), dimana $1 \mathrm{RT}$ $=100 \mathrm{ft}^{3}$ atau setara dengan 2,83 $\mathrm{m}^{3}$.

GT dihitung sesuai Keputusan Dirjen PERLA No. PY.67/1/16-02, dengan rumus sebagai berikut:

$$
\text { GT }=0,25 \times \mathbf{V}
$$

Nilai 0,25 adalah nilai konversi dari satuan meter kubik ke ton register.

$\mathrm{V}=$ adalah jumlah isi dari ruangan di bawah geladak ditambah dengan ruangan-ruangan di atas geladak yang tertutup sempurna yang berukuran tidak kurang dari 1 meter kubik.

$\mathrm{V}=(\mathrm{L} \times \mathrm{B} \times \mathrm{D} \times \mathrm{f})+\mathrm{V}$ bangunan atas

$\mathrm{V}$ bangunan atas diperkirakan $=14 \times 3 \times 2,5$

$=105 \mathrm{~m}^{3}$

$\mathrm{V}=(\mathrm{L} \times \mathrm{B} \times \mathrm{D} \times \mathrm{f})+\mathrm{V}$ bangunan atas

$$
=142,05 \mathrm{~m}^{3}
$$

Sehingga:

$\mathrm{GT}=0,25 \times \mathrm{V}$

$=35,52$

Mendekati 36 GT

$\mathrm{NT}=0,6 \mathrm{GT}=0,6 \times 36=21,6$

NT mendekati 22

\section{KESIMPULAN DAN SARAN}

\section{Kesimpulan}

a. Ukuran utama desain bis air
Panjang seluruh Loa
$=15,10$ meter
Panjang garis air Lwl
$=14,62$ meter
Lebar (breadth)
$=3,70$ meter
Tinggi (depth)
$=1,37$ meter
Sarat (draft)
$=0,86$ meter
Koefisien blok Cb
$=0,55$
Koefisien garis air $\mathrm{Cw} \quad=0,75$
Koefisieb midship Cm $\quad=0,70$
Displacement $\Delta \quad=25,59$ ton
Gross Tonnase GT $\quad=36$

b. Rencana umum bis air kapasitas 30 penumpang dan 2 crews terbuat dari bahan aluminium dengan satu lambung. Bentuk satu lambung pada rencana umum dimaksudkan untuk memudahkan dalam melakukan olah gerak.

c. Bis air didesain dengan kecepatan antara 5 sampai dengan 7 knot, dengan mesin penggerak 2 x 60 hp.

d. Energi Surya

Pemakaian Listrik : 1785 watt

Panel Surya : : 4

Baterai minimum : 3

Bateri 2 hari : 6

e. Periode oleng (rolling period) 10,812 detik harga periode oleng $(\mathrm{t})$ tersebut dianggap baik karena terletak di antara 8 detik sampai dengan 14 detik dan cukup untuk kenyamanan penumpang dan crews.

\section{Saran}

Pemda DKI Jakarta hendaknya mengupayakan untuk menjadikan kanal banjir menjadi infrastruktur atau prasarana transportasi.

\section{DAFTAR PUSTAKA}

Sudjasta, B. dkk, 2012, Perancangan Bis Air Kapasitas 40 Penumpang Sebagai Sarana Transportasi Alternatif Pada Kanal Banjir Timur Provinsi DKI Jakarta, Jurnal Ilmiah FTUPNVJ Bina Teknika Volume 8 Nomor 2 Edisi Desember. 
Delf, Hidroulic the Netherland, Economic and Social Commission for Asia and Pacific, 2000

Nur, Iswadi. 2013, Metode Sederhana Untuk Memilih Jenis Lambung Kapal Kecil (Boat) Sesuai Dengan Fungsinya Berdasarkan Pertimbangan Stabilitas Yang Cocok Agar Dapat Menghindari Kecelakaan Di Laut, Jurnal Ilmiah FT-UPNVJ Bina Teknika Volume 9 Nomor 2 Edisi Desember.

Purnomo, K Kompas.com, "Sampah Ciliwung Meningkat Lima Kali Lipat”, 22 Januari 2012.

Molland, A.F., Turnock, R.S. and Hudson, D.A., 2011, "Ship Resistance and Propulsion: Practical Estimation of Propulsive Power", Cambridge University Press.

Pemda Provinsi DKI Jakarta,’Gambaran Rencana Pembangunan Banjir Kanal Timur, 2003.

Taggart, R., Ed., 1980, "Ship Design and Contruction”, The Society of Naval Architect \& Marine Engineers.

The Japan Society of Naval Architects and Ocean Engineers,”Osa Aqua-Bus” Aqua liner Naniwa No.2”. 